\title{
PEDAGOGY
}

\section{MODERN TEACHER PREPARATION: REALITIES AND PROBLEMS}

\author{
Associate professor, Nazile Abdullazadeh, \\ Doctor of philosophy, Khoshbakht Aliyeva \\ Azerbaijan, Baku, Azerbaijan State Pedagogical University; \\ Head of Department of literature and teaching methods; \\ Doctor of philosophy of Department of literature and teaching methods
}

DOI: https://doi.org/10.31435/rsglobal_wos/31052019/6501

\section{ARTICLE INFO}

Received: 18 March 2019

Accepted: 11 May 2019

Published: 31 May 2019

\section{KEYWORDS}

education, teacher, modern,

problems, realities. \begin{abstract}
As one of the priorities of the state educational policy teacher training was equally worried all of - theorists and practitioners. Systems of primary, secondary, secondary vocational, higher education have two main bases organizing on teachers and educators interests. Deficiencies in one of the parties ultimately show themselves on the others activity.
\end{abstract}

Citation: Nazile Abdullazadeh, Khoshbakht Aliyeva. (2019) Modern Teacher Preparation: Realities and Problems. International Academy Journal Web of Scholar. 5(35). doi: 10.31435/rsglobal_wos/31052019/6501

Copyright: (C) 2019 Nazile Abdullazadeh, Khoshbakht Aliyeva. This is an open-access article distributed under the terms of the Creative Commons Attribution License (CC BY). The use, distribution or reproduction in other forums is permitted, provided the original author(s) or licensor are credited and that the original publication in this journal is cited, in accordance with accepted academic practice. No use, distribution or reproduction is permitted which does not comply with these terms.

"It is necessary learning modern abilities, innovation, be able to think creatively, be motivated, explore research opportunities deeply. We must rise up with stairs tirelessly and resolutely, and every day from the life of student's day have to be one of this stairs. You need learn dealing with the constantly growing treasury of knowledge, a wider stream of scientific information, in a word, you have to be a good expert, who can handle the difficult problems of the day".

Heydar Aliyev

Introduction. Education and its quality had been always a major problem of every nation and state at all times. Teachers preparation, teachers attitude to their profession, preparing the perfect human desire for society, progressive strength humanity were the main aim of history.

Whether society ... or different persons, thinkers knew that society depended on from teachers, emphasized to the profession of teacher and their preparing, and also required from teachers to be deserving them. Socrat compared the teacher with the candle. N. Tusi - philosopher and pedagogue of XIII century defines the professionality of teachers, showed precious different from each - other thoughts about morality and enlightenment, organizational capacity, the behavioral norms of this glorious and difficult professional specialist, on his work "Adabul-mutaalimin". Mustafa Kemal Ataturk called the teaching profession the only force that will save humanity and deserves the highest respect. The great leader Heydar Aliyev always remembered his teachers and spoke about them with all heart and soul". I don't know the highest name, as teacher's name" - saying national lider, giving great attention to preparing of teacher's, and mentioned several time that the future of universe depends on from teachers.

Teacher's preparing took attention not only power of progressive society even took the attention of state and charitable societies. The main problems of teacher's preparation were discussed at the works of I and II congresses of Azerbaijan at the beginning of the XX century. The preparation of national textbooks, preparing unit of education methods, improving the living conditions of rural 
teachers, organizing a special teacher seminary in Azerbaijan, improving and developing women's education had directed at the project of II congress: “...Since the problem of teacher training is one of the most important problems of that time, charitable societies operated many charitable works. For example: with the helping and assistance of these charitable societies on teaching preparing educational centers such as "Medreseyi-ruhani" in Ganja, "Veten mektebi" in Sheki, "Darulmuellimin" and "Qiz mektebleri" which organized by Taqiyev carried great importance.

It was saying about "State Strategy for development of education in Azerbaijan Republic" which adopted in 2013: "The teacher's factor plays a crucial role in the learning process and developing of educator, in the process of monitoring on his achievements. The influence of a teacher on the formation of educator as a competent person depends heavily on the academic abilities of the teacher, teaching experience and professionalism. There is a strong correlation between these qualities of the teacher and the achievements of educators".

Application of the framework document - National Curriculum in Azerbaijan almost come across with the expressions - "modern teacher", "modern lesson", "modern students", "modern teaching methods" with all researchers last times. First of all these questions - "Who is modern teacher and how he must be?", Which qualities have distinguished it from "traditional teacher?", "On which direction must be carry out modern teacher preparing on the new education system?" brings up teachers' profession to agenda.

Connecting with the innovation process of Teacher's Recruitment or during teaching activities, the teacher was assign with different roles; after graduating - to show their rich teaching professionalism, they must have to get properly training, be properly trained not only theoretically, but also practically. First of all:

- teacher-trainer putting forward modern methods of teaching must go to the innovative and active position;

- the learning process should be organized in accordance with the expected types of training;

- teacher training should not be completed by completion of higher education, professional development should be transformed over time into expanded activities, and conditions for permanent training should be established;

- teacher preparing programs should be modernized in accordance with the principles of teaching and learning, teaching practices must be systematically in order to strengthen practical skills (passive and active in the first academic year);

- young teachers - at the beginning of their professional careers should be supported with their stimulating means by innovative experiences (so that, young teachers imitate the older generation which slope of conservatism and their practice in schools)

- according to the national practice must be pass system of internature.

Notes, of course, continue as requirements which given on teacher's preparing, in accordance with its essence and deepening content of the era. In this regard, it is appeared researching and systematizing which qualities have the main meaning and more important in teachers model. Professor M. Ilyasov writes: "A modern teacher is no only source of knowledge, not a transmitter of knowledge, he is knowledge orientation and guide to the path to knowledge. The teacher can achieve his highest level as a result of his indispensable creative activity as an organizer, consultant and partner.

Research results. Today, the teaching staff, which can teach various subjects is based on professional competence and carried out in several higher educational institutions of the country: Thousands of teachers of the new format - young specialists with higher education diplomas were prepared for teaching activities in accordance with the requirements of the society in ASPU, BSU(State), BSU, AUFL, NSU, "Qizlar Universiteti", "Odlar Yurdu", in general, together with 12 public and 10 private schools. Teacher's preparation generalizes a number of factors in itself:

- providing competence in the content of education;

- using and mastering skills of innovative methods and new technologies in training;

- differentiation of training;

- try to preserve the reputation of the teacher anytime, anywhere.

Teacher staffs who graduated higher education should know the laws, forms and methods of logical thinking in their professional activities and competencies, be able to create situate-problems, must be ready for interdisciplinary integration, be able to realize various scientific research. The idea of the great leader Heydar Aliyev, "The future progress of society depends on what and how we teach our young". The idea is the evident proof of this. 
The teacher of the XXI century should be only armed with theoretical knowledge, practical experience, demonstrate ethical relations and high standards of behavior. Today, teacher training is not just knowledge of the subject that he teaches, if a teacher memorizes the standards contend lines of a modern teacher's, he is not considered a teacher. The content of pedagogical education should be used for staff training - as training for stabilize of national moral, esthetic, intellectual, globalized world at a higher educational institution. Regardless of, what subjects is taught, who is university graduate the teacher must be faithful of ideology of statehood, concept of Azerbaijanis, mental values. Only then can we talk about other problems.

As the priority, it should be given teacher's pedagogical skills in teacher's preparation. When it touchers to pedagogical mastery, it is not an understanding of pedagogical education or the meaning of the value of subtlety. No matter how educated, knowledgeable a teacher is, without pedagogical skills he cannot succeed. Pedagogical mastery should first of all manifest itself in the teacher's behavior, facial expression, appearance, image, tone of voice, elocution and events. The teacher must demonstrate the richness of the spiritual world every movement, with his every word.

Speech culture, the beauty of the native language, its using capabilities in place - should be one of the main requirements in teacher's preparing. Teacher-regardless of his profession must seriously carry out ethical norms of speech. Speech culture, speech labels, gestures and facial expressions are considered the basic terms of professional ethics and the main term of teacher's speech. Sh.Gurbanov, I.Shikhli, Kh.R.Uluturk, J.Khandan gained fame as a teacher, attracted an audience with his abilities, reports, conversations, rich and interesting lectures.

U. Hajibeyov wrote: "The teacher is a very difficult and responsible profession. Everyone can't handle it, and you can't call everyone the teacher, and to entrust your children to him - that would be a great mistake. With the exception of one training, teacher is responsible on raising up of children. Since the child is what brings up, and the way he was raised will be the same in the future. The little mistake in brining up, will destroy the future of the child. .... A teacher who has taken up this heavy creative, firstly must take action attentively. The teacher - who took this profession as the Siberian torment, better remove himself from this profession, hard work, responsibility, if he does not teach heartily, doesn't give brightness to knowledge, it is better not to start this work, and better he will give this work professional and begin looking for a profitable job for himself [2, p.128-129].

"A teacher - he is a pedagogical education specialist promoting the development of society, who contributes to the development of society through systematic knowledge, skills and habits, as well as moral qualities. A teacher is a thinker of wide public opinion, a public figure, a person who forms the outlook and faith of people and helps them find their way in life. A teacher is a person, who learned knowledge, abilities, experience and attitudes towards life and teaches others what he has acquired [look: 4] Finally, the teacher is an example of sample.

Despite to the foregoing, teacher's educational effect and reputation is declining in recent years. The objective reason for this is the problems that arise in the process of teacher training, the new education system, including the acquisition of theoretical knowledge, the percentage of experimental knowledge and the superiority of professionalism, the decline in the social status of the teacher, the inability to improve the quality of teacher training, the decline of the teacher's professional culture in recent years, teacher training and employment, the existence of a sharp difference in availability between the number of teachers. It turns outthat the funds allocated for the training of teachers in the country are ultimately ineffective.

Great changing school relations in society, abundance of different social networks and information technologies, going out of the framework of the upbringing from nationality is very close inclination to "Europeanization", changing the individual viewing style based on public awareness, keeping the teacher on the media agenda, at last, teacher's care, removal from thinking as a problem person, who has a problem, creates problems, preserving the past status of the teachers. Besides the teachers, who hold his dignity above all else, who are deeply involved in the profession, and there are teachers who doesn't know about scientific and pedagogical innovations, doesn't try to get over themselves, far from pedagogical ethics and national values. If the first reason is the "loyalty" of the older generation to their traditions - if he can't accept a new one, the second and main is the occasional arrival of the teachers to teaching profession. Everyone who graduates from high school today wants to become a lawyer, a doctor, a lawyer, an economist. When this wish is "inaccessible," choosing the specialty stops on a teacher, on a lawyer, on a semi-historic or on literary teacher, on a desire for a doctor, on a chemist-biologist, on an economist, on geography, and at last who is "on the clothes to stretch the legs" - choose the specialty - teacher in physical education. 
Conclusions. The teaching profession is a constantly changing, dynamic profession. The society trusts the most valuable riches - the child, desires, hopes - to the teacher. As the change of society affects the lifestyle of a person, to her views, to the living, it also affects learning and teaching. In order to build a world-wide, high-tech society, having the power to make Azerbaijan one of the most developed democratic states in the world, to be bound by national and spiritual values and protect them, to love deeply its family, nation, homeland, prepare teachers which connected to origin is the main problem in front of the education system.

\section{REFERENCES}

1. The State Strategy for the Development of Education in the Republic of Azerbaijan. Baku, 2013.

2. Hajibeyli U. Selected Works. Baku: Yazichi, 1985.

3. Ilyasov M. The modern model of the teacher and his basic parameters. /News the series of humanitarian, social and pedagogical-psychological sciences. ASPU, No. 4, 2018, p. 284-293.

4. Materials of the V International Conference "Teacher's Preparing Policy and Problems". April 30 - May 2, 2015, ADPU.

5. Seyidov F.A. Ways of spreading reactionary and progressive Russian educational policy in Azerbaijan at the end of XIX and beginning of XX centuries. Baku: Serkhed, 2007. 